\title{
Analiza możliwości rozwoju i wykorzystania potencjału biogazu rolniczego na cele energetyczne w Polsce
}

\author{
Mariusz Niekurzak (D) \\ AGH Akademia Górniczo-Hutnicza, Wydział Zarządzania, Kraków
}

\begin{abstract}
Streszczenie: Aby osiągnąć założone przez UE cele emisyjne dla Polski, konieczne jest uznanie za priorytet rozwój technologii OZE w ramach sektora energetycznego. W pracy omówiono produkty wykorzystywane do produkcji biogazu, który jest najmniej kapitałochłonnym odnawialnym źródłem energii opartym na uprawach energetycznych oraz przetwarzaniu odpadów. Celem opracowania była analiza bazy surowcowej do pozyskiwania biogazu z bioodpadów oraz określenie wydajności biogazu rolniczego na cele energetyczne na podstawie ogólnego bilansu masowego. Ważna pozycja rolnictwa w gospodarce powoduje, że istotnym kierunkiem rozwoju odnawialnych źródeł energii jest pozyskiwanie i wykorzystanie biogazu. Dotychczasowe źródła biogazu (składowiska odpadów, oczyszczalnie ścieków, biogazownie rolnicze) stanowią jedynie niewielką część jego możliwości produkcyjnych. Obecnie biogaz można produkować w biogazowniach energetycznych wyłącznie z biomasy, np. kiszonki, kukurydzy czy zbóż. Produkcja biogazu na dużą skalę może zapewnić zwiększenie bezpieczeństwa energetycznego kraju, zmniejszenie deficytu gazowego państwa, uniezależnienie się od importu gazu oraz wypełnienie zobowiązań unijnych dotyczących produkcji biopaliw i energii z OZE.
\end{abstract}

Słowa kluczowe: biogaz, energetyczne wykorzystanie, odnawialne źródła energii, ekologia

\section{ANALYSIS OF THE POSSIBILITIES OF \\ DEVELOPING AND USING THE POTENTIAL OF AGRICULTURAL BIOGAS FOR ENERGY PURPOSES IN POLAND}

\begin{abstract}
In order to achieve the emission targets, set by the EU for Poland, it is necessary to consider the development of renewable energy technologies in the energy sector as a priority. This paper discusses the products used for the production of biogas, which is the least capital-consuming renewable energy source based on energy crops and waste processing. The aim of the study was to analyze the raw material base for obtaining biogas from bio-waste and to determine the efficiency of agricultural biogas for energy purposes based on the general mass balance. The advantage of agriculture in the economy means that the direction of development of renewable energy sources is directed towards the acquisition and use of biogas. The existing sources of biogas (landfills, sewage treatment plants, agricultural biogas plants) constitute only a small part of its production capacity. Currently, biogas can be produced in energy biogas plants only from biomass, e.g. silage, maize or cereals. Large-scale production of biogas may mean increasing the country's energy security, reducing the country's gas deficit, becoming independent from gas imports and meeting EU obligations regarding the production of biofuels and energy from renewable sources.
\end{abstract}

Keywords: biogas, energy use, renewable energy source, ecology

https://doi.org/10.7494/978-83-66727-48-9_9 


\section{Wstęp}

Energia jest jednym z najważniejszych czynników warunkujących rozwój państwa. Zasoby surowców energetycznych obecnie są ograniczone i ulegają wyczerpywaniu, podczas gdy - zgodnie z prognozami - szczyt wydobycia ropy naftowej zostanie osiągnięty w latach 2022-2025. Światowe zasoby ropy naftowej, przy zachowaniu obecnych trendów eksploatacyjnych, powinny wystarczyć na około 30 lat, gazu na 40 lat, zaś węgla na 160 lat. Głównym elementem polityki oszczędzania surowców energetycznych jest pozyskanie energii ze źródeł odnawialnych: wiatru, wody, słońca i biogazu. Przystąpienie Polski do Unii Europejskiej zobowiązało nasz kraj do wdrażania i rozwoju sektora odnawialnych źródeł energii. Zgodnie z dyrektywą Unii Europejskiej 2003/30/WE (Dyrektywa... 2003) oraz późniejszą dyrektywą 2009/28/WE (Dyrektywa... 2009) do roku 2030 udział odnawialnych źródeł energii w całkowitym zużyciu energii w naszym kraju powinien wynieść 21-23\%, a udział biogazowni w transporcie powinien osiągnąć rekordowy poziom 8\%. W krajowym planie działania obejmującym energię ze źródeł odnawialnych zakładano, że do 2022 roku w naszym kraju będzie 1080 MW zainstalowanej mocy elektrycznej w biogazowniach. Plany zakładają także, że do 2023 roku powstanie 2 tys. takich instalacji. W końcu roku 2019 w Polsce funkcjonowało 310 biogazowni, w tym tylko 120 biogazowni rolniczych o łącznej mocy elektrycznej 101,3 MW. Obecnie na całym świecie obserwuje się wzrost wykorzystania tego rodzaju odpadów na cele energetyczne, a jednym ze światowych liderów tego trendu może stać się Polska.

W artykule zwrócono uwagę na biogaz jako paliwo bardzo perspektywiczne i o dużym potencjale energetycznym, które do niedawna kojarzone było głównie jako uzupełniające źródło energii elektrycznej i cieplnej wytwarzanej w instalacjach zlokalizowanych wyłącznie na składowiskach odpadów lub przy oczyszczalniach ścieków.

\section{Przegląd literatury}

Biogaz jest produktem beztlenowej fermentacji związków pochodzenia organicznego zawierających celulozę, skrobię oraz inne węglowodory i białka. W prawidłowo prowadzonym procesie fermentacji głównym składnikiem jest metan $\left(\mathrm{CH}_{4}\right)$, który stanowi do 60\% mieszaniny, oraz ditlenek węgla $\left(\mathrm{CO}_{2}\right)$ (Buraczewski i Bartoszek 1990). Dla celów energetycznych biogaz można pozyskać w trzech rodzajach instalacji: w biogazowniach rolniczych, w komorach fermentacyjnych osadów ściekowych oraz w komunalnych oczyszczalniach ścieków i instalacjach odgazowania składowisk komunalnych. Wydajność instalacji do otrzymywania biogazu, a także jakość biogazu rolniczego zależą od wielu czynników, a głównie od: rodzaju substratów wsadowych, stopnia ich przefermentowania, temperatury, w której przebiega fermentacja, obróbki mechanicznej czy też czasu trwania procesu. Baza surowcowa, z której biogaz rolniczy może być pozyskiwany, jest bogata. Stanowią ją bioodpady pochodzenia zwierzęcego oraz produkty i bioodpady pochodzenia roślinnego, ale także miejskiego i przemysłowego. 
Substraty rolnicze do produkcji biogazu to m.in.: odchody zwierzęce (gnojowica, gnojówka, obornik, pomiot kurzy), biomasa z plantacji energetycznych, biomasa uprawiana na glebach gorszej jakości lub na glebach zanieczyszczonych, odpady z produkcji roślinnej (m.in. słoma, odpady zbożowe, np. gorszej jakości ziarno, odpady pasz, odpady drzewne). Substraty komunalne do produkcji biogazu to m.in.: frakcja organiczna odpadów miejskich, odpady zielone pochodzące z pielęgnacji terenów zielonych, odpady ogrodnicze, odpady z placów i targowisk, odpady wytwarzane w gospodarce komunalnej (osad ściekowy). Substraty przemysłowe do produkcji biogazu to m.in. odpady z przemysłu przetwórczego spożywczego, mleczarskiego, cukrowniczego, mięsnego, farmaceutycznego, kosmetycznego i biochemicznego. Substraty te charakteryzują się korzystnym stosunkiem wydajności produkcji biogazu do kosztów ich pozyskania (Błażejewski i in. 2014). Biogazownie rolnicze mogą kupić ten materiał po relatywnie niskiej cenie, a w przypadku umiejscowienia instalacji przy zakładzie produkcyjnym nie ponoszą żadnych kosztów zakupu. Wart podkreślenia jest również fakt, że omawiane powyżej substraty mieszczą się w definicji biomasy, dzięki czemu mogą być legalnie przetwarzane w biogazowniach rolniczych (Pomykała i Łyk 2013).

Jednym $\mathrm{z}$ substratów najpowszechniej stosowanych $\mathrm{w}$ instalacjach biogazowych jest kiszonka z kukurydzy (Curkowski i in. 2009). W roku 2017 do produkcji biogazu wykorzystano ok. 540 tys. ton kiszonki. Typowa biogazownia o mocy $1 \mathrm{MW}$ energii elektrycznej dziennie zużywa 70-80 ton substratu z kukurydzy. Po to, by biogazownia mogła skutecznie pracować, wymagana jest uprawa kukurydzy na areale przekraczającym 450 ha. Chociaż produkcja biogazu z kiszonki kukurydzy jest bardzo opłacalna ekonomicznie, to - biorąc pod uwagę zagrożenie gleby brakiem zmienności upraw i w konsekwencji jej wyjałowienie i narażenie na choroby - nie zaleca się monokultury upraw. Obok kukurydzy najczęściej wykorzystywanym substratem w Polsce w instalacjach biogazowych jest gnojowica, której w 2017 roku zużyto około 720 tys. ton (Budowa biogazowni..., b.d.). Odpady po produkcji zwierzęcej są mokre, więc zagrożenie unieruchomieniem pomp w instalacji biogazowej, która dopuszcza w materiale stosowanym jako wsad energetyczny jedynie około $17 \%$ masy suchej, jest niewielkie (Misiaczyk 2007). Wszelkie przestoje spowodowane zatykaniem się pomp w instalacji prowadzą do mniejszej produkcji biogazu i strat ekonomicznych. Innymi bardzo popularnymi substratami stosowanymi jako wsad w polskich biogazowniach są pozostałości z owoców i warzyw (ok. 500 tys. ton rocznie) oraz wywar gorzelniany (ok. 450 tys. ton rocznie). Są to substraty o wysokim potencjale energetycznym (Gostomczyk 2012) i, jeśli instalacja znajduje się blisko źródła ich wytwarzania, mogą być także relatywnie tanie, co znacząco podnosi opłacalność biogazowni.

Szansą na rozwój wykorzystania biogazu w Polsce jest duży potencjał energetyczny krajowego rolnictwa. Szacuje się, że potencjał surowcowy umożliwia wytworzenie rocznie 5-6 mld $\mathrm{m}^{3}$ biogazu o parametrach jakościowych gazu ziemnego wysokometanowego. Potencjał ten zakłada wykorzystanie w pierwszej kolejności produktów ubocznych rolnictwa, płynnych i stałych odchodów zwierzęcych oraz produktów ubocznych i pozostałości 
przemysłu rolno-spożywczego (Głaszczka i in. 2010). Równocześnie z wykorzystaniem tych surowców przewiduje się prowadzenie upraw roślinnych, w tym określanych jako energetyczne, z przeznaczeniem na substrat dla biogazowni. Jest to możliwe docelowo na około 700 tys. ha, co pozwoli na pełne zaspokojenie krajowych potrzeb żywnościowych oraz pozyskanie surowców niezbędnych do wytwarzania biopaliw i biogazu (Klimiuk $\mathrm{i}$ in. 2012). W szacunkach rolniczego potencjału produkcyjnego uwzględniono zmiany, jakie wynikają z rozwoju budownictwa mieszkaniowego, usług i produkcji oraz infrastruktury transportowej. Przyjmuje się, że wzrost popytu w naturalny sposób wywoła wzrost podaży, w tym przypadku produkcji i dostaw surowców energetycznych. Należy również zaznaczyć, że zwiększenie wykorzystania biogazu rolniczego powstałego z produktów ubocznych rolnictwa, płynnych i stałych odchodów zwierzęcych oraz pozostałości przemysłu rolno-spożywczego przyczyni się do wzrostu dochodów rolników dzięki spożytkowaniu niezagospodarowanych dotychczas odpadów oraz pozwoli na zachowanie podstawowej funkcji rolnictwa, którą jest produkcja żywności przy jednoczesnej produkcji znaczących ilości energii (Lewandowski i Ryms 2013).

\section{Metodyka badań}

Celem badań było określenie, ile biogazu można wyprodukować z surowców rolniczych. Na podstawie zgromadzonych danych i przyjętych założeń przeprowadzono obliczenia pozwalające oszacować potencjał energetyczny biogazu wyprodukowanego z surowców rolniczych z uwzględnieniem ogólnego bilansu masy.

\section{Założenie oraz dane przyjęte do obliczeń}

Podstawowym surowcem do produkcji biogazu była kiszonka kukurydzy zwyczajnej. Odpady hodowli bydła, tj. gnojowica oraz odpady z gospodarstw domowych, stanowily kosubstraty. Kukurydza po zbiorze i rozdrobnieniu została zakiszana w silosach, po czym za pomocą podajnika kiszonka $\left(Q_{\text {kiszonka }}\right)$ została przetransportowana do dwóch komór fermentacji (A i B), które działały w systemie jednoczesnym. Ponadto do komór doprowadzone zostały gnojowica $\mathrm{z}$ hodowli bydła $\left(Q_{\text {gnojowica }}\right)$, odpady organiczne $\left(Q_{o d p a d y}\right)$ i woda procesowa $\left(M_{A, \text { woda }} ; M_{B, \text { woda }}\right)$, tak aby umożliwić rozcieńczenie wsadu surowcowego do stężenia suchej masy $10 \%$. Fermentację metanową przeprowadzono w warunkach mezofilowych w temperaturze $(T) 39^{\circ} \mathrm{C}$. Hydrauliczny czas zatrzymania wsadu surowcowego $(t)$ wynosił 45 dni. Wyprodukowany biogaz $\left(Q_{\text {biogaz }}\right)$ magazynowany był w zbiornikach umieszczonych w stropie komór fermentacyjnych, a następnie został poddany oczyszczaniu. Po tym procesie, biogaz (zawierający 58\%) został umieszczony w zewnętrznych zbiornikach, w celu przetworzenia go na energię cieplną lub elektryczną w agregacie kogeneracyjnym. Fermentat $\left(Q_{\text {odp.ferment. }}\right)$ transportowany był z komór fermentacji do zbiornika magazynowania za pomocą zaworów spustowych i tam magazynowany przez $100 \mathrm{dni}$, w celu dofermentowania. Dane do obliczeń przyjęto na podstawie tabeli 1. 


\section{Tabela 1}

Założenia oraz dane przyjęte do obliczeń (surowiec podstawowy: kiszonka z kukurydzy zwyczajnej, kosubstrat: gnojowica z hodowli bydła, odpady organiczne)

\begin{tabular}{|c|c|c|c|}
\hline Parametr & Symbol & Jednostka & Wartość \\
\hline \multicolumn{4}{|c|}{ Wydajność biogazowni } \\
\hline Moc agregatu kogeneracyjnego & $W$ & $\mathrm{~kW}$ & 150 \\
\hline Sprawność przetwarzania energii elektrycznej & $\eta_{e l}$ & $\%$ & 38 \\
\hline Stosunek energii elektrycznej do cieplnej & $e l: e c$ & - & 1016317 \\
\hline \multicolumn{4}{|c|}{ Źródła biomasy do fermentacji } \\
\hline $\begin{array}{l}\text { Wydajność świeżej masy zielonki i kukurydzy } \\
\text { zwyczajnej }\end{array}$ & $Q_{k u k u r y d z a}$ & $\mathrm{t} /($ ha $\cdot$ rok $)$ & 45 \\
\hline Straty w procesie zbioru i konserwacji & $\eta_{\text {straty }}$ & $\%$ & 12 \\
\hline Rezerwa kiszonki na dwumiesięczną produkcję & $\eta_{\text {rezerwa }}$ & $\%$ & 17 \\
\hline Pogłowie bydła (krowy mleczne) & $n$ & szt. & 100 \\
\hline Produkcja gnojowicy bydlęcej & JPD & $\mathrm{dm}^{3} /(\mathrm{d} \cdot \mathrm{szt})$. & 60 \\
\hline Produkcja odpadów organicznych & $Q_{\text {odpadv }}$ & $\mathrm{kg} / \mathrm{d}$ & 55 \\
\hline \multicolumn{4}{|c|}{$\begin{array}{ll}\text { Charakterystyka surowców } \\
\end{array}$} \\
\hline \multicolumn{4}{|l|}{ Kiszonka z kukurydzy zwyczajnej: } \\
\hline zawartość wody w kiszonce kukurydzy zwyczajnej & $C_{\text {woda,kiszonka }}$ & $\%$ & 65 \\
\hline stężenie substancji organicznych & $C_{\text {S.m.o.,kiszonka }}$ & $\%$ s.m. & 95 \\
\hline ciężar właściwy & $\rho_{\text {kiszonka }}$ & $\mathrm{g} / \mathrm{cm}^{3}$ & 0,6 \\
\hline \multicolumn{4}{|l|}{ Odpady organiczne: } \\
\hline zawartość wody w odpadach organicznych & $C_{\text {woda,odpady }}$ & $\%$ & 70 \\
\hline stężenie substancji organicznych & $C_{\text {S.m.o.odpady }}$ & $\%$ s.m. & 90 \\
\hline ciężar właściwy & $\rho_{\text {odpady }}$ & $\mathrm{g} / \mathrm{cm}^{3}$ & 0,6 \\
\hline \multicolumn{4}{|l|}{ Gnojowica $\mathrm{z}$ hodowli bydła: } \\
\hline zawartość wody w gnojowicy bydlęcej & $C_{\text {woda,gnojowica }}$ & $\%$ & 92 \\
\hline stężenie substancji organicznych & $C_{\text {S.m.o., gnojowica }}$ & $\%$ s.m. & 75 \\
\hline ciężar właściwy & $\rho_{\text {gnojowica }}$ & $\mathrm{g} / \mathrm{cm}^{3}$ & 0,97 \\
\hline \multicolumn{4}{|c|}{ Parametry wydajności biogazu } \\
\hline Współczynnik wydajności biogazu & $Y_{\text {biogaz }}$ & & \\
\hline Kiszonka z kukurydzy zwyczajnej & $Y_{\text {biogaz,kiszonka }}$ & & 0,6 \\
\hline Odpady organiczne & $Y_{\text {biogaz,odpady }}$ & $\mathrm{m}^{3} / \mathrm{kg}$ s.m.o. & 0,35 \\
\hline Gnojowica $\mathrm{z}$ hodowli bydła & $Y_{\text {biogaz, gnojowica }}$ & & 0,3 \\
\hline Stężenie metanu w biogazie & $C_{\text {metan }}$ & $\%$ & 58 \\
\hline Wartość opałowa metanu & $e$ & $\mathrm{kWh} / \mathrm{m}^{3}$ & 10 \\
\hline \multicolumn{4}{|c|}{ Parametry technologiczne fermentacji } \\
\hline Stężenie suchej masy w komorze fermentacji & $C_{\text {s.m.,komora }}$ & $\%$ & 10 \\
\hline Temperatura fermentacji & $T$ & ${ }^{\circ} \mathrm{C}$ & 39 \\
\hline Hydrauliczny czas zatrzymania & $t$ & $\mathrm{dm}^{3} /(\mathrm{d} \cdot \mathrm{szt})$. & 45 \\
\hline Sprawność usuwania związków organicznych & $\eta_{\text {s.m.o. }}$ & $\%$ & 60 \\
\hline Współczynnik wydajności biomasy & $Y$ & kg/(kg s.m.o.) & 0,1 \\
\hline Ciepło właściwe surowca & $c$ & $\mathrm{kWh} /(\mathrm{kg} \cdot \mathrm{K})$ & $1,16 \cdot 10^{-3}$ \\
\hline
\end{tabular}

Źródło: opracowanie własne na podstawie Podkówka (2012) 
W celu określenia zapotrzebowania na substrat podstawowy, tj. kiszonkę kukurydzy zwyczajnej, należy:

- wyznaczyć wymaganą dobową produkcję biogazu dla agregatu kogeneracyjnego o założonej mocy $(E)$,

- wyznaczyć produkcję dobową biogazu z gnojowicy z hodowli bydła $\left(Q_{\text {biogaz,gnojowica }}\right)$,

- obliczyć produkcje dobową biogazu z odpadów organicznych ( $\left.Q_{\text {biogaz,odpady }}\right)$,

- oszacować dobowe zapotrzebowanie na kiszonkę kukurydzy zwyczajnej i na tej podstawie określić areał uprawy.

\section{Wyniki badań}

Cel badań zrealizowano zgodnie z metodologią obliczeniową przedstawioną poniżej. WIELKOŚĆ PRODUKCJI BIOGAZU

- Ilość energii wymaganej dla agregatu kogenaracyjnego o założonej mocy $E[\mathrm{kWh} / \mathrm{d}]$ :

$$
E=\frac{24 W}{\frac{n_{e l}}{100}}=63,16
$$

- Ilość wytworzonej energii elektrycznej (el) i cieplnej $(e c)[\mathrm{kWh} / \mathrm{d}]$ :

$$
e l=24 \mathrm{kWh}
$$

$$
e c=1,6317 e l=39,16
$$

- Produkcja dobowa biogazu wymagana dla uzyskania potrzebnej ilości energii $Q_{\text {biogaz }}$ $\left[\mathrm{m}^{3} / \mathrm{d}\right]$ :

$$
Q_{\text {biogaz }}=\frac{E}{\frac{C_{\text {metan }}}{100} e}=10864,83
$$

- Produkcja dobowa biogazu z gnojowicy z hodowli bydła $Q_{\text {biogaz,gnojowica }}\left[\mathrm{m}^{3} / \mathrm{d}\right]$ :

- Mokra masa gnojowicy z hodowli bydła $Q_{\text {gnojowica }}[\mathrm{kg} / \mathrm{d}]$ :

$$
Q_{\text {gnojowica }}=n J P D \rho_{\text {gnojowica }}=5820
$$

- Sucha masa gnojowicy z hodowli bydła $Q_{\text {gnojowica,s.m. }}[\mathrm{kg} / \mathrm{d}]$ :

$$
Q_{\text {gnojowica,s.m. }}=Q_{\text {gnojowica }} \cdot\left(\frac{100-C_{\text {woda,gnojowica }}}{100}\right)=456,6
$$


- Sucha masa organiczna gnojowicy z hodowli bydła $Q_{\text {gnojowica,s.m.o. }}[\mathrm{kg} / \mathrm{d}]$ :

$$
Q_{\text {gnojowica,s.m.o. }}=Q_{\text {gnojowica,s.m. }} \cdot \frac{C_{\text {s.m.o.gnojowica }}}{100}=349,2
$$

- Produkcja dobowa biogazu z gnojowicy z hodowli bydła $Q_{\text {biogaz,gnojowica }}\left[\mathrm{m}^{3} / \mathrm{d}\right]$ :

$Q_{\text {biogaz, gnojowica }}=Q_{\text {gnojowica,s.m.o. }} \cdot Y_{\text {biogaz, gnojowica }}=104,7$

- Produkcja dobowa biogazu z odpadów organicznych (suchą masę i suchą masę organiczną odpadów organicznych oraz produkcję dobową biogazu obliczono analogicznie jak w przypadku gnojowicy z hodowli bydła):

- Mokra masa odpadów organicznych $Q_{\text {odpady }}[\mathrm{kg} / \mathrm{d}]$ :

$$
Q_{o d p a d y}=3600
$$

- Sucha masa odpadów organicznych $Q_{\text {odpady,s.m. }}[\mathrm{kg} / \mathrm{d}]$ :

$$
Q_{\text {odpady,s.m. }}=1080
$$

- Sucha masa organiczna odpadów organicznych $Q_{\text {odpady,s.m.o. }}[\mathrm{kg} / \mathrm{d}]$ :

$$
Q_{\text {odpady,s.m.o. }}=972
$$

- Produkcja dobowa biogazu z odpadów organicznych $Q_{\text {biogaz,odpady }}\left[\mathrm{m}^{3} / \mathrm{d}\right]$ :

$$
Q_{\text {biogaz,odpady }}=340,2
$$

- Produkcja dobowa biogazu z kiszonki kukurydzy zwyczajnej $Q_{\text {biogaz,kiszonka }}\left[\mathrm{m}^{3} / \mathrm{d}\right]$ :

$$
Q_{\text {biogaz, kiszonka }}=Q_{\text {biogaz }}-Q_{\text {biogz, gnojowica }}-Q_{\text {biogaz, odpady }}=10419,87
$$

\section{ZAPOTRZEBOWANIE NA KISZONKE KUKURYDZY ZWYCZAJNEJ}

- Dzienne zapotrzebowanie na mokrą masę kiszonki kukurydzy zwyczajnej $Q_{k i s z o n k a}$ $[\mathrm{kg} / \mathrm{d}]$ :

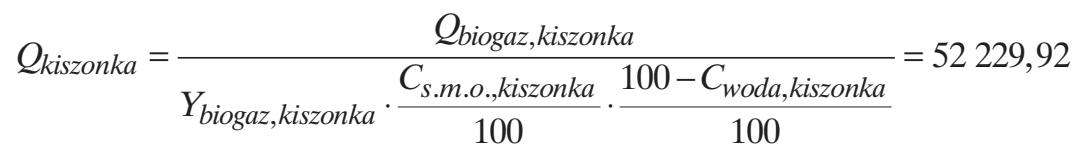

- Roczne zapotrzebowanie na mokrą masę kiszonki kukurydzy zwyczajnej $Q_{\text {kiszonka,rok }}[\mathrm{t} / \mathrm{rok}]$

$$
Q_{\text {kiszonka,straty }}=365 Q_{\text {kiszonka }}=19063922,56
$$


- Straty kukurydzy zwyczajnej podczas zbioru i konserwacji $Q_{\text {kiszonka,straty }}[\mathrm{t} / \mathrm{rok}]$ :

$$
Q_{\text {kiszonka,straty }}=Q_{\text {kiszonka,rok }} \cdot \frac{\eta_{\text {straty }}}{100}=2287670,7
$$

- Rezerwa kiszonki na dwumiesięczną produkcję $Q_{\text {kiszonka,rezerwa }}[\mathrm{t} / \mathrm{rok}]$ :

$$
Q_{\text {kiszonka,rezerwa }}=Q_{\text {kiszonka,rok }} \cdot \frac{\eta_{\text {rezerwa }}}{100}=3240866,84
$$

- Całkowite zapotrzebowanie na kiszonkę kukurydzy zwyczajnej $Q_{\text {kiszonka,suma }}$ [t/rok]:

$$
Q_{k i s z o n k a, s u m a}=Q_{k i s z o n k a, r o k}+Q_{k i s z o n k a, \text { straty }}+Q_{k i s z o n k a, \text { rezerwa }}=21592460,1
$$

- Wymagana powierzchnia gruntów ornych $A$ [ha] na produkcję kukurydzy zwyczajnej:

$$
A=\frac{Q_{\text {kiszonka,suma }}}{Q_{\text {kukurydza }}}=479832,45
$$

\section{KOMORY FERMENTACJI}

- Łączna masa wsadu surowcowego kierowanego do komór fermentacji $[\mathrm{kg} / \mathrm{d}]$; do obliczeń przyjęto rozdział surowców między komorami A i B przedstawiony w tabeli 2 .

\section{Tabela 2}

Rozdział surowców między komorami A i B

\begin{tabular}{|l|c|c|}
\hline \multicolumn{1}{|c|}{ Rodzaj surowca } & Komora A & Komora B \\
\hline Kiszonka kukurydzy zwyczajnej [\%] & 50 & 50 \\
\hline Gnojowica z hodowli bydła [\%] & 50 & 50 \\
\hline Odpady organiczne [\%] & 50 & 50 \\
\hline
\end{tabular}

- Komora A:

- Masa mokrego wsadu $\Sigma Q_{A, \text { surowiec }}[\mathrm{kg} / \mathrm{d}]$ :

$$
\sum Q_{A, \text { surowiec }}=\frac{1}{2}\left(Q_{\text {kiszonka }}+Q_{\text {gnojowica }}+Q_{\text {odpady }}\right)=30824,96
$$

- Sucha masa wsadu surowcowego $\Sigma Q_{A, \text { surowiec,s.m. }}[\mathrm{kg} / \mathrm{d}]$ :

$$
\sum Q_{A, \text { surowiec,s.m. }}=\frac{1}{2}\left(Q_{\text {kiszonka,s.m. }}+Q_{\text {gnojowica,s.m. }}+Q_{o d p a d y, \text { s.m. }}\right)=1686,83
$$


- Sucha masa organiczna wsadu surowcowego $\Sigma Q_{A \text {,surowiec,s.m.o. }}[\mathrm{kg} / \mathrm{d}]$ :

$$
\begin{aligned}
\sum Q_{A \text {,surowiec,s.m.o. }} & =\frac{1}{2}\left(Q_{\text {kiszonka,s.m.o. }}+Q_{\text {gnojowica,s.m.o. }}+Q_{\text {odpady,s.m.o. }}\right)= \\
& =1528,93
\end{aligned}
$$

- Komora B:

- Masa mokrego wsadu $\Sigma Q_{B, \text { surowiec }}[\mathrm{kg} / \mathrm{d}]$ :

$$
\sum Q_{B, \text { surowiec }}=\frac{1}{2}\left(Q_{\text {kiszonka }}+Q_{\text {gnojowica }}+Q_{\text {odpady }}\right)=30824,96
$$

- Sucha masa wsadu surowcowego $\Sigma Q_{B, \text { surowiec,s.m. }}[\mathrm{kg} / \mathrm{d}]$ :

$$
\sum Q_{B, \text { surowiec,s.m. }}=\frac{1}{2}\left(Q_{k i s z o n k a, s . m .}+Q_{\text {gnojowica,s.m. }}+Q_{o d p a d y, s . m .}\right)=1686,83
$$

- Sucha masa organiczna wsadu surowcowego $\Sigma Q_{B, \text { surowiec,s.m.o. }}[\mathrm{kg} / \mathrm{d}]$ :

$$
\begin{aligned}
\sum Q_{B, \text { surowiec,s.m.o. }} & =\frac{1}{2}\left(Q_{\text {kiszonka,s.m.o. }}+Q_{\text {gnojowica,s.m.o. }}+Q_{\text {odpady,s.m.o. }}\right)= \\
& =1528,93
\end{aligned}
$$

- Masa wody procesowej niezbędna do otrzymania założonego stężenia suchej masy w komorach fermentacji A i B $M_{\text {woda }}[\mathrm{kg} / \mathrm{d}]$ :

$\sum Q_{A, \text { surowiec,s.m. }}-10 \%$ (stężenie suchej masy w komorze fermenatcji)

$x-100 \%$

$M_{A, \text { woda }}=x \sum Q_{A, \text { surowiec }}=15181,47$

$M_{B, \text { woda }}=x \sum Q_{B, \text { surowiec }}=15181,47$

- Masa odpadów pofermentacyjnych $Q_{\text {odp.ferment. }}[\mathrm{kg} / \mathrm{d}]\left(Q_{\text {odp.ferment. }}=\right.$ substancje organiczne, które nie uległy konwersji w biogaz w komorach fermentacji A i B + pozostałość mineralna + woda procesowa + namnożona biomasa w komorach fermentacji A i B):

$Q_{\text {odp.ferment. }}=97716,16$ 
- Zapotrzebowanie na ciepło na ogrzanie wsadu surowcowego kierowanego do komór fermentacji A i B $Q_{c}[\mathrm{kWh} / \mathrm{d}]$; do obliczeń należy przyjąć, że temperatura wsadu surowcowego wynosi $15^{\circ} \mathrm{C}=273,15 \mathrm{~K}$ :

$Q_{c}=m c \Delta T=19534$

gdzie:

$m$ - masa wsadu surowcowego kierowana do komór fermentacji A i B [kg/d],

$c$ - ciepło właściwe osadu $[\mathrm{kWh} /(\mathrm{kg} \cdot \mathrm{K})]$,

$\Delta T$ - różnica temperatury pomiędzy osadem w komorze fermentacji a substratem $[\mathrm{K}]$.

- Produkcja energii cieplnej $e c_{\text {netto }}[\mathrm{kWh} / \mathrm{d}]$ :

$e c_{\text {netto }}=e c-Q_{c}=764,95$

\section{WIELKOŚĆ OBIEKTÓW W UKŁADZIE TECHNOLOGICZNYM}

- Objętość silosów do zakiszania i składowania kiszonki kukurydzy zwyczajnej $V_{\text {silos }}$ $\left[\mathrm{m}^{3}\right]$ :

$V_{\text {silos }}=\frac{Q_{\text {kiszonka, suma }}}{\rho_{\text {kiszonka }}}=35987,43$

- Objętość zbiornika wstępnego na gnojowicę z hodowli bydła $V_{\text {gnojowica }}\left[\mathrm{m}^{3}\right]$; do obliczeń należy przyjąć, że czas zatrzymania gnojowicy w zbiorniku wynosi 10 dni oraz że $25 \%$ objętości zbiornika zajmuje powietrze oraz osprzęt techniczny:

$$
V_{\text {gnojowica }}=10 \cdot 1,25 \frac{Q_{\text {gnojowica }}}{\rho_{\text {gnojowica }}}=75000
$$

- Objętość komór fermentacji $\left[\mathrm{m}^{3}\right]$; do obliczeń należy przyjąć, że gęstość surowców po zmieszaniu w komorach fermentacji $1^{\circ} \rho_{w} \approx 1,0 \mathrm{~g} / \mathrm{cm}^{3}$ oraz że $25 \%$ objętości komory zajmuje biogaz oraz osprzęt techniczny:

$$
\begin{aligned}
& V_{A}=\left(\frac{Q_{A, \text { surowiec }}+M_{A, \text { woda }}}{1000}\right) t \cdot 1,25=2587,86 \\
& V_{B}=\left(\frac{Q_{B, \text { surowiec }}+M_{B, \text { woda }}}{1000}\right) t \cdot 1,25=2587,86
\end{aligned}
$$


- Objętość zbiornika na odpady pofermentacyjne $V_{\text {odp.ferment. }}\left[\mathrm{m}^{3}\right]$; do obliczeń należy przyjąć, że czas zatrzymania odpadów w zbiorniku wynosi 100 dni oraz że 25\% objętości zbiornika zajmuje powietrze oraz osprzęt techniczny:

$$
V_{\text {odp.ferment. }}=\frac{Q_{\text {odp.ferment. }}}{1000} 100 \cdot 1,25=12214,52
$$

- Objętość zbiornika na biogaz $V_{z b i o r n i k, b i o g a z}\left[\mathrm{~m}^{3}\right]$; do obliczeń należy przyjąć, że stosunek objętości komory fermentacji do objętości zbiornika na biogaz wynosi:

$$
\begin{aligned}
& \frac{V_{A}+V_{B}}{V_{z \text { biornik, biogaz }}}=\frac{1}{2} \\
& V_{\text {zbiornik,biogaz }}=10351,44
\end{aligned}
$$

\section{OGÓLNY BILANS MASOWY}

Po wykonaniu wszystkich obliczeń zbudowano diagram przedstawiający bilans masowy (tab. 3) surowców i produktów do instalacji przetwarzającej na biogaz kiszonkę kukurydzy zwyczajnej, odpady organiczne oraz gnojowicę z odpadów bydła.

\begin{tabular}{|c|c|c|c|}
\hline \multirow{4}{*}{ Komora A } & $\begin{array}{c}\text { kiszonka kukurydzy zwyczajnej } \\
{[\mathrm{kg} / \mathrm{d}]} \\
52229,92\end{array}$ & \multirow{4}{*}{$\begin{array}{l}\text { biogaz }\left[\mathrm{m}^{3} / \mathrm{d}\right] \\
\quad 10864,82\end{array}$} & \\
\hline & $\begin{array}{l}\text { gnojowica z hodowli bydła }[\mathrm{kg} / \mathrm{d}] \\
5820\end{array}$ & & \\
\hline & $\begin{array}{l}\text { odpady organiczne }[\mathrm{kg} / \mathrm{d}] \\
3600\end{array}$ & & \\
\hline & $\begin{array}{c}\text { woda procesowa [ } \mathrm{kg} / \mathrm{d}] \\
15181,47\end{array}$ & & \\
\hline \multirow{4}{*}{ Komora B } & $\begin{array}{c}\text { kiszonka kukurydzy zwyczajnej } \\
{[\mathrm{kg} / \mathrm{d}]} \\
52229,92\end{array}$ & \multirow{4}{*}{$\begin{array}{c}\text { biogaz }\left[\mathrm{m}^{3} / \mathrm{d}\right] \\
10864,82\end{array}$} & \\
\hline & $\begin{array}{l}\text { gnojowica z hodowli bydła }[\mathrm{kg} / \mathrm{d}] \\
5820\end{array}$ & & \\
\hline & $\begin{array}{l}\text { odpady organiczne }[\mathrm{kg} / \mathrm{d}] \\
3600 \\
\end{array}$ & & \\
\hline & $\begin{array}{l}\text { woda procesowa }[\mathrm{kg} / \mathrm{d}] \\
15181,47\end{array}$ & & $\begin{array}{c}\text { odpady pofermentacyjne } \\
{[\mathrm{kg} / \mathrm{d}]} \\
97716.16\end{array}$ \\
\hline
\end{tabular}

Tabela 3

Ogólny bilans masowy 


\section{Dyskusja}

Na podstawie wykonanych obliczeń można stwierdzić, że wydajność biogazu z kiszonki i kukurydzy waha się $w$ granicach $170-220 \mathrm{~m}^{3} \cdot \mathrm{t}^{-1}$ s.m., natomiast wydajność gnojowicy to $20-36 \mathrm{~m}^{3} \cdot \mathrm{t}^{-1} \mathrm{~s} . \mathrm{m}$. Zawartość metanu w kiszonce z kukurydzy wynosi 50-55\%, a w gnojowicy świńskiej 60-70\%, co pozwoli na roczny uzysk biogazu na poziomie ok. $6968000 \mathrm{~m}^{3}$. Przyjmując wartość opałową pozyskanego biogazu w przedziale 23-27 $\mathrm{MJ} \cdot \mathrm{m}^{-3}$, można szacować, że pozyskana ilość biogazu pozwala wyprodukować około 5,3-5,5 kWh energii, a roczna produkcja prądu może wynieś około 16000 MWh. Otrzymany uzysk można wykorzystać np. w 40\% na energię elektryczną $(2,1 \mathrm{kWh})$, w $45 \%$ na energię cieplną $(2,4 \mathrm{kWh})$, a $0,8 \mathrm{kWh}$ wynoszą straty poniesione w procesie wytwarzania energii. Każdy $1 \mathrm{~m}^{3}$ biogazu rolniczego w efekcie pozwala zasilić 21 żarówek 100-watowych przez godzinę. Wyprodukowany w tak dużej ilości biogaz pozwala na zainstalowanie dwóch modułów kogeneracyjnych o mocy 2 MWh pracujących przez około 8 tys. godz.

Polska jest krajem o bardzo dużym potencjale produkcji biogazu. Wynika to przede wszystkim z dobrze rozwiniętego sektora produkcji żywności, a także dużej powierzchni użytków rolnych. Należy jednak pamiętać, że w procesie fermentacji metanowej powinny być wykorzystane przede wszystkim odpady organiczne i biomasa odpadowa z rolnictwa (Ustawa ... 2017). Duża ilość odpadów generowanych przez przemysł rolno-spożywczy może przyczynić się do budowy wielu instalacji biogazowych znajdujących się przy źródle ich wykorzystania, tj. zakładzie produkcyjnym.

Bardzo duże możliwości w zakresie wzrostu udziału źródeł odnawialnych w polskim miksie energetycznym wiążą się z wykorzystaniem biopaliw. Biogaz jest wykorzystywany zarówno do produkcji energii elektrycznej, jak i w sektorach ciepłowniczym, chłodniczym oraz transportowym. W skali całej UE, z biopaliw wyprodukowano w 2019 roku 5,4\% energii elektrycznej, a krajami z największym ich udziałem były Finlandia (18,5\%), Estonia (17,1\%), Dania (16,9\%) oraz Łotwa (14,4\%). W Polsce udział biopaliw w produkcji energii elektrycznej wyniósł 4,6\%. Z kolei w wartościach bezwzględnych na pierwszym miejscu znalazły się Niemcy, które wyprodukowały w 2019 roku 45 TWh energii elektrycznej z biopaliw, co stanowiło 26\% całkowitej produkcji w krajach UE. Szczególną uwagę warto zwrócić na biogaz. Europejscy liderzy, Niemcy, produkują 33 razy więcej tego paliwa niż Polska. Szacuje się, że polski potencjał produkcji biogazu może osiągnąć 31 TWh, co stanowiłoby $18 \%$ obecnej produkcji energii elektrycznej w Polsce. Czynnikiem blokującym rozwój biogazowni w Polsce jest przede wszystkim niewystarczający system dofinansowań, zwłaszcza na początkowych etapach inwestycji, której koszt przerasta możliwości finansowe wielu rolników (Głodek 2007). Oprócz podwyższenia nakładów należałoby rozszerzyć obecnie funkcjonujący system wsparcia produkcji biogazu, także na produkcję biometanu. Pod względem liczby biogazowni w przeliczeniu na populację Polska zajmuje dopiero 24. miejsce w Europie. Tymczasem biorąc pod uwagę potencjał przetwarzania odpadów rolniczych można szacować, że Polska mogłaby wy- 
twarzać rocznie 13,5 mld $\mathrm{m}^{3}$ biogazu. W przypadku rozpoczęcia hodowli kukurydzy na cele energetyczne w podobnej skali, jak ma to miejsce w Niemczech, szacowany potencjał produkcji energii elektrycznej z biogazu mógłby wynieść do $8 \mathrm{GW}$. Zestawiając tę wartość ze średnim miesięcznym krajowym zapotrzebowaniem na moc (22-25,5 GW), można stwierdzić, że biogaz mógłby zaspokoić nawet 30\% dziennego zapotrzebowania na moc w Polsce.

\section{Podsumowanie}

Wykonana analiza wskazuje, że w przypadku gospodarstw zajmujących się hodowlą i produkcją roślinną istnieją przesłanki, by uzyskać odpowiednią ilość odpadów do produkcji biogazu, a w konsekwencji do wytwarzania energii elektrycznej oraz cieplnej. Produkcja biogazu może się odbywać na bazie materiału odpadowego pochodzenia rolniczego zarówno zwierzęcego, jak i roślinnego. Wykorzystanie substratu w postaci mieszaniny gnojowicy z kiszonką z kukurydzy zapewnia uzyskanie około $6968000 \mathrm{~m}^{3}$ ilości biogazu, możliwość utylizacji gnojowicy oraz produkcję około $16000 \mathrm{MWh}$,zielonej energii elektrycznej" w układach kogeneracyjnych. Koferment kiszonki z kukurydzy użyty do produkcji biogazu ma duży potencjał energetyczny i stabilną jakość, dzięki czemu możliwe jest planowanie zapasów na potrzeby zaopatrzenia biogazowni. Ponadto stosowanie biopaliw wpływa korzystnie na środowisko, ponieważ ogranicza wykorzystywanie naturalnych zasobów paliw kopalnianych oraz przyczynia się do zmniejszenia efektu cieplarnianego. Produkcja biogazu rolniczego pozwala też wykorzystać odpady przemysłu rolno-spożywczego oraz wytwarzany przez gospodarstwa rolne obornik i odpady roślinne do produkcji zarówno ekologicznego paliwa, jak i nawozów naturalnych. Dzięki temu można zapobiec zagrożeniu przedostawania się biogazu do atmosfery, co przyczynia się do zmniejszania efektu cieplarnianego oraz ogranicza ryzyko powstawania niekontrolowanych pożarów spowodowanych wypalaniem odpadów przez rolników. W procesie produkcji biogazu rolniczego, wykorzystując mniejszą ilość substratów (obornika i odpadów roślinnych), można wyprodukować o około $50 \%$ więcej produktu finalnego niż podczas produkcji biogazu wysypiskowego, ze względu na skład biochemiczny substratów, a co za tym idzie - prostszy i bardziej opłacalny sposób ich fermentacji.

W Polsce biogaz jest obecnie postrzegany jako nowy i budzący wiele wątpliwości substytut paliw konwencjonalnych, a nie jako źródło przynoszące szereg korzyści środowiskowych i ekonomicznych. Dlatego też duży nacisk kładzie się na zwiększenie naszej wiedzy na ten temat. Już w 2022 roku Polska ma produkować co najmniej $3 \mathrm{mld}^{3}$ biogazu - takie są założenia programu przygotowanego w Ministerstwie Rolnictwa. Eksperci przekonują, że Polska posiada wiele niewykorzystanych odpadów powstałych w rolnictwie i przetwórstwie rolno-spożywczym, które zamiast trafiać na wysypiska lub do utylizacji, powinny być źródłem biogazu. Możliwość zastosowania do produkcji biogazu wielu substratów oraz unijne i krajowe wsparcie dla tego typu inwestycji powinny spowodować, że Polska będzie miała szansę stać się dużym producentem biogazu. 


\section{Literatura}

Błażejewski W., Gąsior P., Kaleta J., Kułażyński M., 2014, Magazynowanie biogazu oraz wykorzystanie jako paliwa do silnika spalinowego, Politechnika Wrocławska, Wrocław.

Budowa biogazowni rolniczej krok po kroku, b.d., Biogaz - Biogazownia Rolnicza Krok po Krok, https://biogazowniakrokpokroku.pl/budowa-biogazowni-rolniczej-krok-pokroku/ [dostęp: 10.10.2021].

Buraczewski G., Bartoszek B., 1990, Biogaz: wytwarzanie i wykorzystanie, Państwowe Wydawnictwo Naukowe, Warszawa.

Curkowski A., Mroczkowski P., Oniszk-Popławska A., Wiśniewski G., 2009, Biogaz rolniczy - produkcja i wykorzystanie, Mazowiecka Agencja Energetyczna Sp. z o.o., Warszawa

Dyrektywa 2003/30/WE Parlamentu Europejskiego i Rady z dnia 8 maja 2003 r. w sprawie wspierania użycia $w$ transporcie biopaliw lub innych paliw odnawialnych, Dz. Urz. UE L 123 z 17.05.2003.

Dyrektywa Parlamentu Europejskiego i Rady 2009/28/WE z dnia 23 kwietnia 2009 r. $w$ sprawie promowania stosowania energii ze źródet odnawialnych zmieniajaca $i$ w nastęstwie uchylajac a dyrektywy 2001/77/WE oraz 2003/30/WE, Dz. Urz. UE L 140 z 5.06.2009.

Głaszczka A., Wardal J.W., Romaniuk W., Domasiewicz T., 2010, Biogazownie rolnicze, MULTICO Oficyna Wydawnictwa, Warszawa.

Głodek E. (red.), 2007, Pozyskiwanie i energetyczne wykorzystanie biogazu rolniczego, Wydawnictwo Instytut Śląski Sp. z o.o., Opole.

Gostomczyk W., 2012, Efektywność substratów do produkcji biogazu, Politechnika Koszalińska, Koszalin, https://www.imp.gda.pl/bf2020/BF2012/prezentacje/p141.pdf [dostęp: 10.10.2021].

Klimiuk E., Pawłowska M., Pokój T., 2012, Biopaliwa: technologie dla zrównoważonego rozwoju, Wydawnictwo Naukowe PWN, Warszawa.

Lewandowski W., Ryms M., 2013, Biopaliwa: proekologiczne odnawialne źródła energii, Wydawnictwo WNT, Warszawa.

Misiaczyk B., 2007, Biogaz rolniczy, Agroenergetyka, http://agroenergetyka.pl/?a=article\&id=35 [dostęp: 10.10.2021].

Podkówka W. (red.), 2012, Biogaz rolniczy - odnawialne źródto energii: teoria i praktyczne zastosowanie, Powszechne Wydawnictwo Rolnicze i Leśne, Warszawa.

Pomykała R., Łyk P., 2013, Biogaz z odpadów (bio)paliwem dla transportu: bariery i perspektyw, Chemik, vol. 67, nr 5, s. 454-461.

Ustawa z dnia 10 kwietnia 1997 r. Prawo energetyczne, Dz.U. 1997 nr 54 poz. 348, t.j. Dz.U. 2017 poz. 220. 